\title{
Meningkatkan Kemampuan Menulis Mahasiswa Program Studi PG-PAUD melalui Pendekatan Saintifik
}

\author{
Sance A. Lamusu ${ }^{\bowtie}$ \\ Bahasa dan Sastra Indonesia, Universitas Negeri Gorontalo \\ DOI: $10.31004 /$ obsesi.v5i1.609
}

\begin{abstract}
Abstrak
Penelitian ini bertujuan untuk mendeskripsikan kemampuan mahasiswa PG-PAUD dalam menulis resensi buku pendidikan anak usia dini melalui pendekatan saintifik. Subjek penelitian mahasiswa program studi PG-PAUD di Universitas Negeri Gorontalo yang berjumlah 32 orang. Jenis penelitian yang digunakan penelitian tindakan kelas. Pengumpulan data menggunakan instrumen dalam bentuk tes dan observasi. Teknik analisis data yaitu kualitatif dan kuantitaif. Hasil penelitian menunjukkan bahwa peningkatan keberhasilan secara klasikal dari 66,41 pada siklus I, menjadi $86,77 \%$ pada siklus II terjadi peningkatan sekitar 20,36 \%. Dapat disimpulkan bahwa pendekatan saintifik dapat meningkatkan kemampuan menulis resensi buku pendidikan anak usia dini pada mahasiswa program studi PG-PAUD.
\end{abstract}

Kata Kunci: kemampuan menulis; pendekatan saintifik; mahasiswa pg-paud.

\begin{abstract}
This study describes the ability of early childhood education teacher education students in writing book reviews for early childhood education through a scientific approach. The research subjects are 32 early education teacher education students at Gorontalo State University. This type of research used classroom action research. Data collection using instruments in the form of tests and observations. Data analysis techniques are qualitative and quantitative. The results showed that the classical success increased from 66.41 in the first cycle, to $86.77 \%$ in the second cycle an increase of about $20.36 \%$. It can be concluded that the scientific approach can improve the ability to write a book review of early childhood education in early childhood education teacher education students departement.
\end{abstract}

Keyword: writing skills; scientific approach; student education teacher early childhood education

Copyright (c) 2020 Sance A. Lamusu

$\triangle$ Corresponding author:

Email Address : sancelamusu@yahoo.com (Gorontalo, Indonesia)

Received 19 June 2020, Accepted 25 June 2020, Published 25 June 2020 


\section{PENDAHULUAN}

Setiap hari manusia tidak lepas dari berbahasa. Kegiatan berbahasa dapat dilakukan dengan bahasa lisan dan bahasa tulis. Bahasa memiliki peran yang sangat penting bagi perkembangan manusia. Kemampuan berbahasa terdiri dari menyimak, berbicara, membaca serta menulis (Jayaningrum et al., 2019; Pebriana, 2017). Dari keempat keterampilan tersebut tidak dapat dipisahkan karena digunakan dalam kehidupan sehari-hari.

Sebagai mahasiswa kemampuan berbahasa khususnya menulis diperlukan dalam kehidupan akademik (Ansoriyah \& Rahmat, 2018; Persadha, 2016). Kemampuan menulis merupakan makna ganda yang artinya untuk kepentingan pribadi dan mampu membimbing calon peserta didik. Selain itu, kemampuan menulis menjadi sarana untuk dapat menemukan sesuatu, dapat memunculkan ide baru bagi penulis, dapat melatih kemampuan mengorganisasikan, dapat menjernihkan bermacam konsep atau ide, melatih sikap objektif pada diri seseorang, dapat membantu menyerap dan memproses infotmasi, serta melatih untuk berpikir aktif (Sulistia-dewi, 2018). Sedangkan Gereda (2014) menyatakan bahwa menulis merupakan sebuah kemampuan seseorang dalam menyampaikan gagasan ke dalam sebuah wacana supaya diterima oleh pembaca, baik secara intelektual maupun social.

Menurut Jacobs et al., dalam (Persadha, 2016) terdapat lima aspek dalam menilai kemampuan menulis mahasiswa diantaranya adalah 1) kemampuan mengembangkan isi makalah ilmiah, 2) kemampuan mengorganisasi makalah ilmiah, 3) kemampuan menggunakan kosakata, 4) kemampuan menggunakan bahasa makalah ilmiah, 5) kemampuan menerapkan ejaan dan teknik penulisan makalah ilmiah pada mahasiswa program studi PG-PAUD.

Sedangkan menurut Musaffak (2013) Kemampuan menulis penting dikuasai oleh mahasiswa karena dapat meningkatkan kualitas diri di perguruan tinggi. Kemampuan menulis yaitu kegiatan yang dilakukan oleh mahasiswa dengan menggabungkan pengetahuan intelektual serta berpikir logis yang menggunakan pilihan bahasa efektif dan komunikatif untuk diungkapkan dalam bentuk tulisan atau karya ilmiah. Mahasiswa akan menjadi guru, sedangkan peranan guru salah satunya adalah meneliti yang diungkapkan dalam tulisan (Alwiyah \& Imaniyati, 2018; Hulukati \& Rahmi, 2020; Maiza \& Nurhafizah, 2019; Muhson, 2004; Sum \& Taran, 2020; Zubaidi, 2020). Untuk itu, kemampuan menulis pada mahasiswa sangatlah penting. Kemampuan menulis yang harus dimiliki oleh kalangan mahasiswa/akademis berupa makalah, laporan praktikum, laporan buku, laporan penelitian (skripsi, tesis, disertasi), resensi.

Resensi merupakan sebuah tulisan atau ulasan mengenai nilai sebuah karya tulis yaitu buku. Komaidi (2007) menyatakan bahwa resensi adalah sebagai bahan pertimbangan atau perbincangan tentang sebuah buku yang menilai kelebihan dan kekurangan buku, menarik tidaknya tema dan isi buku, kritikan, dan memberi dorongan kepada khalayak tentang perlu tidaknya buku tersebut dibaca dan dimiliki. Adapun unsur dalam menulis resensi yaitu judul resensi, menyusun data buku (judul buku, pengarang, penerbit, tahun terbit berserta cetakannya, dimensi buku, harga buku), isi resesnsi buku, dan penutup resensi buku.tahapan yang dapat digunakan dalam penulisan resensi ialah 1) Tahap persiapan, memilih jenis buku yang akan diresesnsi, buku baru, dan membuat anatomi, 2) Tahap pengerjaan. Membaca detail dan mencatat hal penting seperti kutipan dan kata-kata. Dimulai dengan membuat informasi umum tentang buku, menentukan judul resesnsi, membuat ringkasan secara garis besar, memberikan penilaian buku, menonjolkan sisi lain dari buku yang diresensi, mengulas manfaat buku tersebut bagi pembeca, menilai kelengkapan karya, EYD dan sistematika resensi.

Berdasarkan observasi yang dilakukan pada 32 orang mahasiswa dalam proses pembelajaran resensi menunjukkan 46,8\% mahasiswa belum mencapai ketuntasan minimal yang telah ditetapkan sebelumnya yaitu 65 . Kurang berhasilnya pembelajaran menulis resensi pada mahasiswa program studi pendidikan anak usia dini. Hal ini disebabkan 
karena pembelajaran berorientasi pada dosen, kurangnya pemberian materi cara menulis yang tepat dan benar, kurangnya kesempatan mahasiswa berlatih menulis sehingga menghambat untuk belajar menulis dengan aktif serta kreatif. Selain itu, mahasiswa masih mengalami kesulitan kebahasaan seperti masalah kesesuaian, ejaan, tanda baca, keefektifan kalimat, kepaduan paragraf, keruntutan, pilihan kata. Sependapat dengan Agustin (2017) strategi/pendekatan pembelajaran yang kurang tepat mempengaruhi pembelajaran sehingga menjadi kurang efektif untuk kemampuan menulis resensi. Sedangkan pendapat Ansoriyah \& Rahmat (2018) berpendapat bahwa pembelajaran menulis lebih ditekankan pada teori yang menyebabkan mahasiswa bosan dan tidak menarik untuk menulis.

Berdasarkan masalah tersebut maka diperlukannya pendekatan untuk meningkatkan kemampuan menulis resensi mahasiswa program pendidikan guru pendidikan anak usia dini. Menurut penelitian (J. Nugraha et al., 2019) menunjukkan bahwa pendekatan saintifik dapat meningkatkan kemampuan menulis dengan peningkatan siklus I dan II cukup signifikan mencapai $28 \%$ dan target indikator ketercapaian diperoleh $75 \%$ dari seluruh seluruh jumlah anak tercapai bahkan ada yang melebihi target yaitu $88 \%$. Sependapat dengan hasil penelitian (Laia, 2016) bahwa pendekatan saintifik dapat meningkatkan kemampuan menulis puisi pada 21 orang anak, hal ini tampak pada siklus I nilai rata-rata anak 66,23 atau $33,33 \%$. Pada siklus II nilai rata-rata anak meningkat menjadi 75,48 atau $90,47 \%$.

Berdasarkan hasil penelitian tersebut, maka peneliti menggunakan pendekatan saintifik untuk meningkatkan kemampuan menulis resensi mahasiswa program studi PGPAUD. Pendekatan saintifik adalah pembelajaran yang yang melalui suatu kegiatan atau learning by doing (Wakhidah, 2018). Pendekatan saintifik dalam pembelajaran meliputi mengamati, menanya, mencoba, mengolah dan mengkomunikasikan (Setiawan, 2017). Menurut Helmawati et al., (2015) pendekatan saintifik dipandang cocok dalam meningkatkan kemampuan menulis, karena pendekatan saintifik memiliki langkah-langkah pembelajaran secara alamiah dan jelas. Langkah-langakah yang digunakan dalam pembelajaran dalam meningkatkan kemampuan menulis mahasiswa dapat diarahkan untuk melaksanakan lima kegiatan seperti mengamati, menanya, menalar, mengkomunikasikan. Rumusan masalah dalam penelitian ini adalah bagaimana meningkatkan kemampuan menulis mahasiswa PG-PAUD melalui pendekatan saintifik? Kemudian tujuan dari penelitian ini adalah mendeskripsikan kemampuan menulis resensi buku pendidikan anak usia dinidengan menggunakan pendekatan saintifik.

Keterbaruan penelitian yaitu dilakukan pada mahasiswa PG-PAUD di Universitas Negeri Gorontalo dan berfokus pada kemampuan menulis resensi buku pendidikan anak usia dini. Penelitian sebelumnya oleh Agustin (2017) peningkatan kemampuan menulis resensi novel menggunakan strategi permodelan dengan subjek siswa kelas XI IPA 3 SMA Negeri 1 Baregbeg. Sedangkan penelitian Nugraha et al., (2018) pembelajaran menulis resensi novel pertemuan dua hati dan laskar pelangi menggunakan teknik, dengan subjek mahasiswa program studi bahasa dan sastra Indonesia. Impak dari penelitian ini adalah mahasiswa memiliki kemampuan menulis resensi buku dengan cara ulasan mengenai nilai sebuah karya tulis serta menilai kelebihan dan kekurangan buku, menarik tidaknya tema dan isi buku, kritikan, dan memberi dorongan kepada khalayak tentang perlu tidaknya buku tersebut dibaca dan dimiliki.

\section{METODOLOGI}

Jenis penelitian yang digunakan dalam penelitian ini yaitu penelitian tindakan kelas dari Kemmis \& Mc Taggart (1998) yang terdiri dari perencanaan (planning), tindakan (action), pengamatan (observasi), dan refleksi (reflection). Subjek penelitian mahasiswa program studi PG-PAUD yang berjumlah 32 terdiri dari 6 laki-laki dan 26. Pengumpulan data menggunakan instrument dalam bentuk tes dan observasi. Data dan sumber data berupa skor yang diperoleh melalui tes hasil kemampuan menulis mahasiswa PG-PAUD. 

DOI: 10.31004/obsesi.v5i1.609

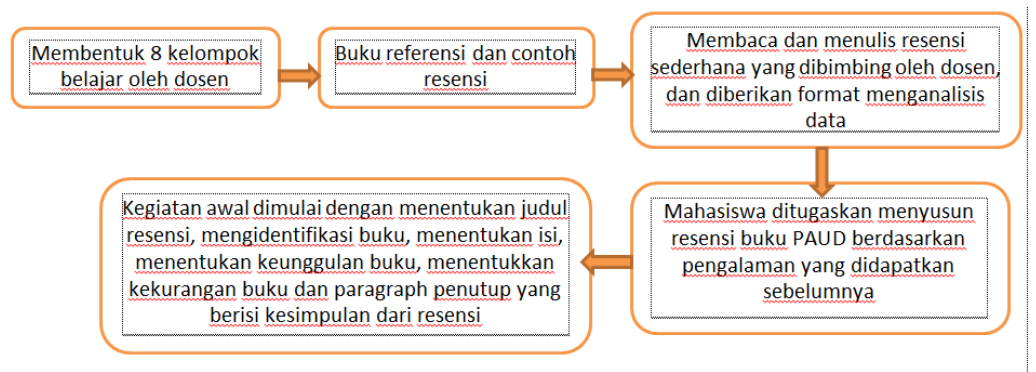

Gambar 1. Tahap Pelaksanaan Penelitian

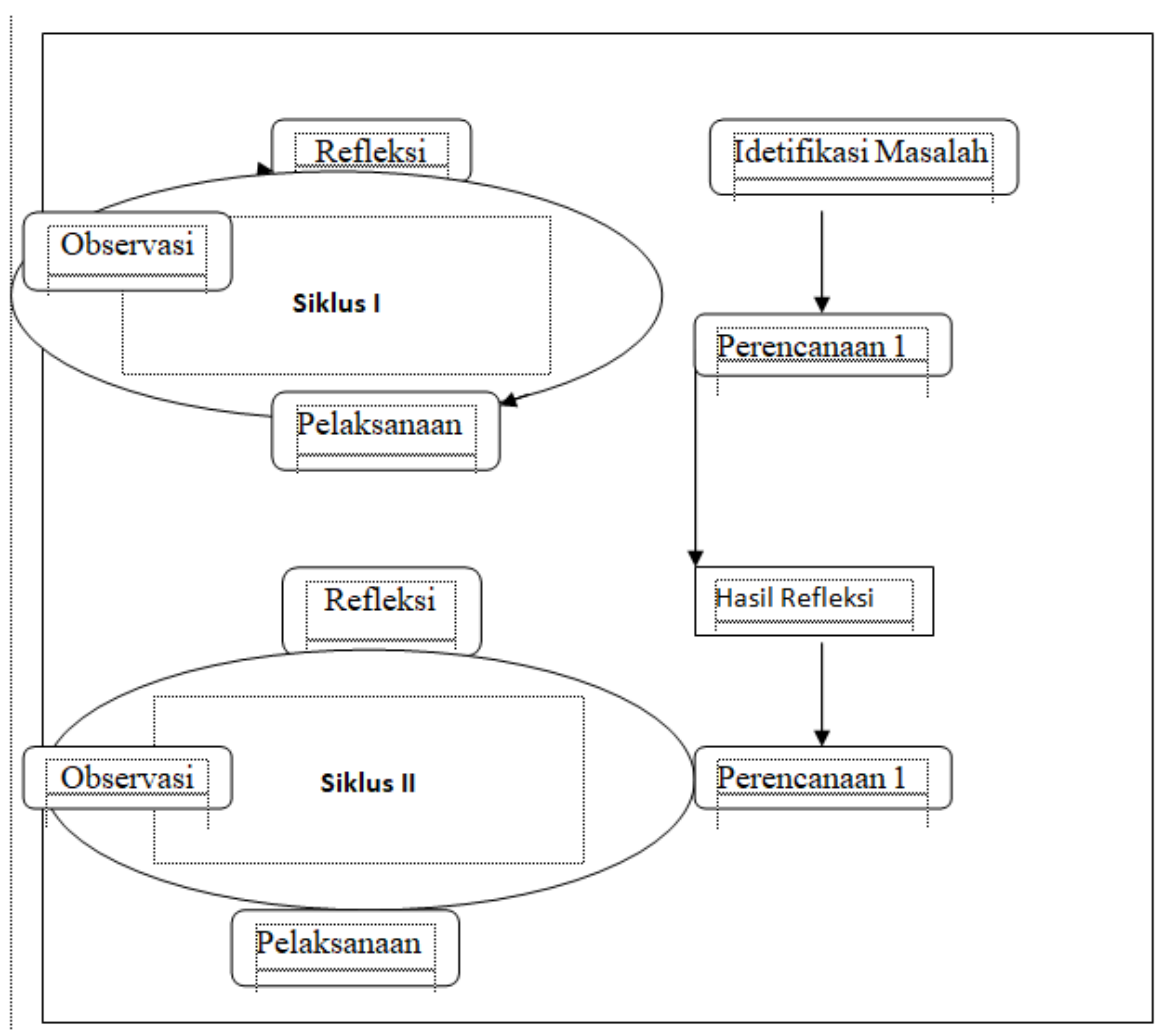

Gambar 2. Siklus Pelaksanaan Tindakan

Teknik analisis data yaitu kualitatif dan kuantitaif. Pada kualitatif peneliti menggunakan analisis dari Miles \& Huberman (2007). Sedangkan kuantitaif menggunakan Penafsiran Acuan Patokan (PAP) oleh Suyanto (1997) untuk menetapkan tingkat keberhasilan mahasiswa PG-PAUD.

Tabel 1. Penafsian Acuan Patokan

\begin{tabular}{|c|c|c|}
\hline \multirow{2}{*}{ No } & \multicolumn{2}{|c|}{ Penafsiran Acuan Patokan } \\
\cline { 2 - 3 } & Presentase & Penafsiran \\
\hline 1 & $90 \%-100 \%$ & Sangat baik \\
\hline 2 & $80 \%-89 \%$ & Baik \\
\hline 3 & $65 \%-79 \%$ & Cukup \\
\hline 4 & $55 \%-64 \%$ & Kurang \\
\hline 5 & $<55 \%$ & Kurang sekali \\
\hline
\end{tabular}


Adapun rubrik dari penilian menulis resensi sebagai berikut:

\begin{tabular}{|c|c|c|c|}
\hline \multicolumn{4}{|c|}{$\begin{array}{c}\text { Tabel 3 } \\
\text { Format Aspelk Penilaian Menulis Resensi }\end{array}$} \\
\hline No & $\begin{array}{l}\text { Aspek Yang } \\
\text { diNilai }\end{array}$ & Bobot & Deskriptor \\
\hline \multirow[t]{4}{*}{1} & \multirow[t]{4}{*}{ Judul Resensi } & 4 & $\begin{array}{l}\text { menguasai aturan penelitian; tidal; terdapat } \\
\text { kesalahan ejaen, tanda baca, penggunaen hurf } \\
\text { kaspital, dan relevan dengan isi bulku }\end{array}$ \\
\hline & & 3 & $\begin{array}{l}\text { menguasai aturan penelitian; terdispat sadikit } \\
\text { kesalahan ejaen, tanda baca, penggunaen huruf } \\
\text { kapital, dan relevan dengan isi bulus }\end{array}$ \\
\hline & & 2 & $\begin{array}{l}\text { menguasai sturan penalitian; terdapst sadikit } \\
\text { kesalahan ejan, kesalahan tanda baca, kaslahan } \\
\text { penggunaen huruf kapital, dan relevan dengan isi } \\
\text { bulku }\end{array}$ \\
\hline & & 1 & $\begin{array}{l}\text { menguasai aturan penelitian; banyalk kesalahan } \\
\text { ejann, tands baca, kesalahan penggunaen hur } \\
\text { kapital, dantidak relevan dengan isi buku }\end{array}$ \\
\hline \multirow[t]{4}{*}{2} & \multirow[t]{4}{*}{ Identitas Bulu } & 4 & $\begin{array}{l}\text { terdigst judul bulku, nama pengarang, penerbit, } \\
\text { cetakan, jumlah halaman. }\end{array}$ \\
\hline & & 3 & $\begin{array}{l}\text { terdgagt judul bulku, tidalk mencantumkan nama } \\
\text { pengarang, penerbit, cetaksn, jumlah halaman. }\end{array}$ \\
\hline & & 2 & $\begin{array}{l}\text { terdagat judul bulku, tidalk mencantumkan nama } \\
\text { pengarang, tidak mencantumkan penerbit, cetalsan, } \\
\text { jumlah halaman. }\end{array}$ \\
\hline & & 1 & $\begin{array}{l}\text { terdspat judul bulku, tidalk mencantumlsan nama } \\
\text { pengarang, tidak mencantumkan penerbit, cetakan, } \\
\text { jumlah halaman tidak lengksp }\end{array}$ \\
\hline \multirow[t]{2}{*}{3} & \multirow[t]{2}{*}{$\begin{array}{l}\text { Isi } \\
\text { penting/menarik }\end{array}$} & 4 & $\begin{array}{l}\text { menguasai topik tulisan; pengembangan } \\
\text { pembuksan sacara lengkap; relevan dengan topik } \\
\text { yang dibahas }\end{array}$ \\
\hline & & 3 & menguasai topik tulisan; pengenbangan \\
\hline
\end{tabular}

\begin{tabular}{|c|c|c|c|}
\hline & & & $\begin{array}{l}\text { pembulksan kurang lengksp; relevan dengan topik } \\
\text { yang dibahas }\end{array}$ \\
\hline \multirow{6}{*}{4} & \multirow{6}{*}{ Bahasa Pengarang } & 2 & $\begin{array}{l}\text { menguasai topik tulisan; pengembangan } \\
\text { pembulksen secara lengksa; hurang relevan dengan } \\
\text { topik yang dibahas }\end{array}$ \\
\hline & & 1 & $\begin{array}{l}\text { menguasai topik tulisan; pengembangan } \\
\text { pembuksaen tidalk lengkap; tidak relevan dengan } \\
\text { topik yang dibahas }\end{array}$ \\
\hline & & 4 & $\begin{array}{l}\text { mengursiksan bahasa pengarang kalimat efelktif dan } \\
\text { komunikatif, diksi variatif, tepat, dan menarik, } \\
\text { tidak ada kalimat yang ambigu }\end{array}$ \\
\hline & & 3 & $\begin{array}{l}\text { menguraikan bahasa pangarang kalimat kurang } \\
\text { efeltif dan komunikatif, diksi variatif, tepat, den } \\
\text { menarik, tidak ada kalimat yang ambigu }\end{array}$ \\
\hline & & 2 & $\begin{array}{l}\text { menguraikan bahasa pengarang kalimat kurang } \\
\text { efeltif dan komurilkatif, diksi kurang variatif, } \\
\text { tepat, dan menarik, tidak ada kalimat yang ambigu }\end{array}$ \\
\hline & & 1 & $\begin{array}{l}\text { menguraikan bahasa pengarang kalimat hurang } \\
\text { efeltif dan komunikatif, diksi kurang variatif, } \\
\text { tepat, dan menarik, kalimat yang ambigu }\end{array}$ \\
\hline \multirow[t]{3}{*}{5} & \multirow[t]{3}{*}{ Keunggulan Bukru } & 4 & $\begin{array}{l}\text { menguraikan kelebihan bulku, manfast buku, } \\
\text { rekomendasi kepada pembaca den dideskripsikan } \\
\text { secara jelas. }\end{array}$ \\
\hline & & 3 & $\begin{array}{l}\text { menguraikan kelebihan bulku, tidalk menguraikan } \\
\text { manfast buku, rekomendesi kepada pembaca den } \\
\text { dideskripsikan secara jelas. }\end{array}$ \\
\hline & & 2 & $\begin{array}{l}\text { menguraikan kelebihan bulku, tidalk menguraikan } \\
\text { manfast buku, rekomendasi keppada pembaca dan } \\
\text { tidalk dideskripsikan sacara jelas. }\end{array}$ \\
\hline \multirow[t]{2}{*}{6} & \multirow[t]{2}{*}{ Bahasa Pengarang } & 4 & $\begin{array}{l}\text { menguraiksan bahasa pengarang kalimat efaltif dan } \\
\text { komuunikatif, diksi variatif, tepast, dan menarik, } \\
\text { tidalk ada kalimat yang ambigu }\end{array}$ \\
\hline & & 3 & \begin{tabular}{|l|l|} 
menguraikan bahas pangarang kalimat kurang \\
efeltif dan komurikatifi, diksi variatif, tepat, dan
\end{tabular} \\
\hline
\end{tabular}

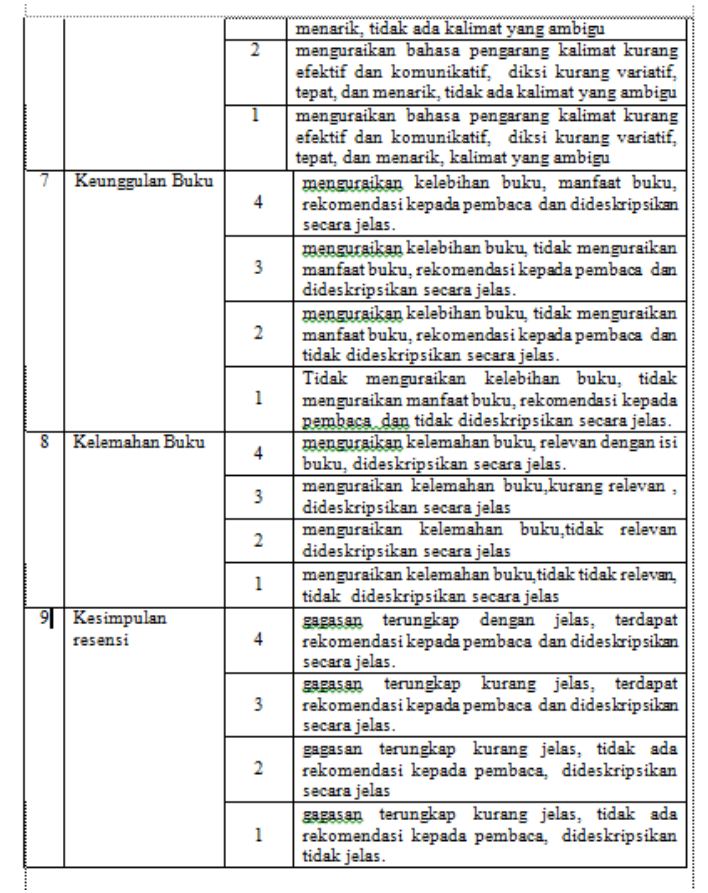

Gambar 3. Rubrik penilaian kemampuan menulis resensi

\section{HASIL DAN PEMBAHASAN}

\section{Hasil Siklus I Evaluasi Belajar Mahamahasiswa Program Studi PG-PAUD}

Agar dapat mengetahui peningkatan kemampuan menulis resensi buku pendidikan anak usiai dini, maka pada akhir siklus pertama diadakan evaluasi tertulis. Tes tertulis berupa menulis resensi buku pendidikan anak usia dini, kemudian mahasiswa menulis resensi dengan memperhatikan kelengkapan unsur-unsur resensi. Hasil pekerjaan mahasiswa diteliti dan diperiksa dengan menggunakan rubrik penilaian menulis. Hasil tersebut secara sederhana dapat dilihat pada grafik berikut. 


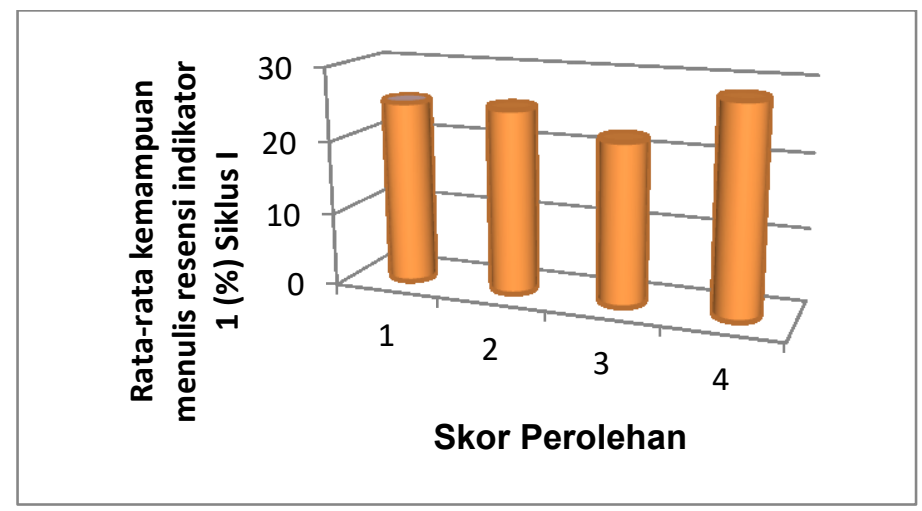

Gambar 4. Persentase Siklus I Hasil Kemampuan Menulis Indikator 1

Berdasarkan gambar di atas menunjukkan bahwa hasil kemampuan mahasiswa menulis resensi buku PAUD pada siklus I. dari 32 orang mahasiswa dapat dianalisis 7 aspek yang dinilai yaitu : indikator (1) Menentukan judul resensi buku pendidikan anak usia dini, terdapat 9 mahasiswa yang dapat menentukan judul sangat tepat atau 28,12\%. Mahasiswa yang menjawab tepat 7 orang atau $21,87 \%$. Ada 8 orang mahasiswa yang menjawab kurang tepat atau $25 \%$, sedangkan yang menjawab tidak tepat ada 8 orang mahasiswa sama dengan $25 \%$.

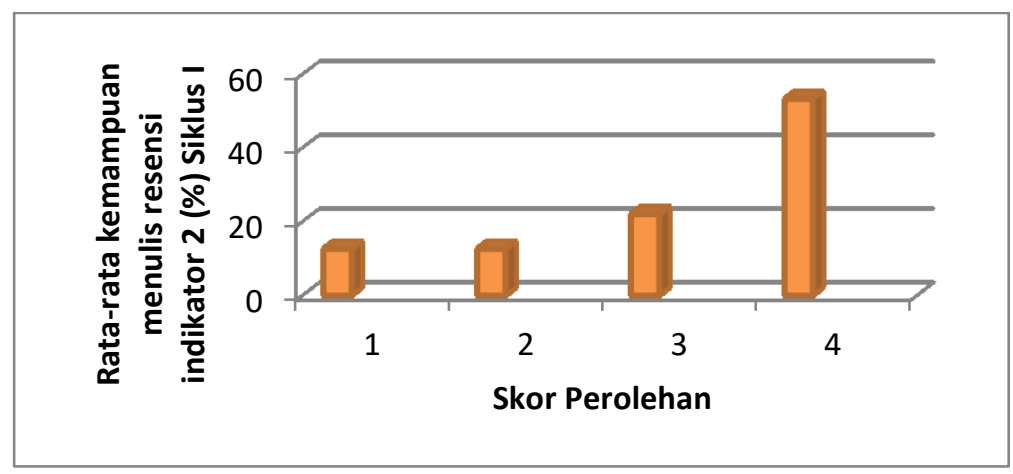

Gambar 5. Persentase Kemampuan Menulis Resensi Indikator 2

Gambar 5 di atas adalah indikator ke II tampak kemampuan mahasiswa menentukan identitas buku yang diresensi. Dari 32 orang mahasiswa yang sangat tepat dalam menuliskan identitas buku yang diresensi 17 orang mahasiswa atau 53,12 \%. Mahasiswa yang tepat menentukan identitas buku berjumlah 7 orang mahasiswa atau $21,87 \%$. Sementara yang kurang tepat menentukan identias buku yang diresensi ada 4 orang mahasiswa atau $12,5 \%$, begitu pula dengan mahasiswa yang tidak tepat menentukan identitas buku ada 4 orang mahasiswa atau $12,5 \%$.

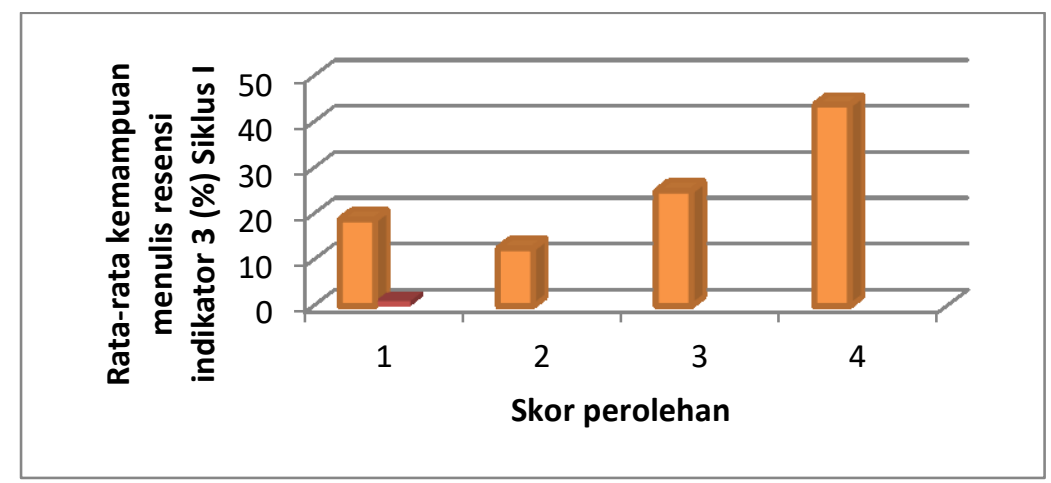

Gambar 6. Persentase Hasil Evaluasi Indikator 3 
Berdasarkan indikator ke 3, terlihat kemampuan mahasiswa menentukan isi atau materi penting resensi buku dari 32 orang mahasiswa terdapat 14 orang yang mampu menjawab dengan sangat tepat, atau $43,75 \% .8$ orang mahasiswa yang menjawab tepat atau $25 \%$, sementara mahasiswa yang kurang tepat menguraikan isi materi berjumlah 4 orang atau 12,5. Sedangkan 6 orang mahasiswa menjawab tidak tepat atau 18,75 \%.

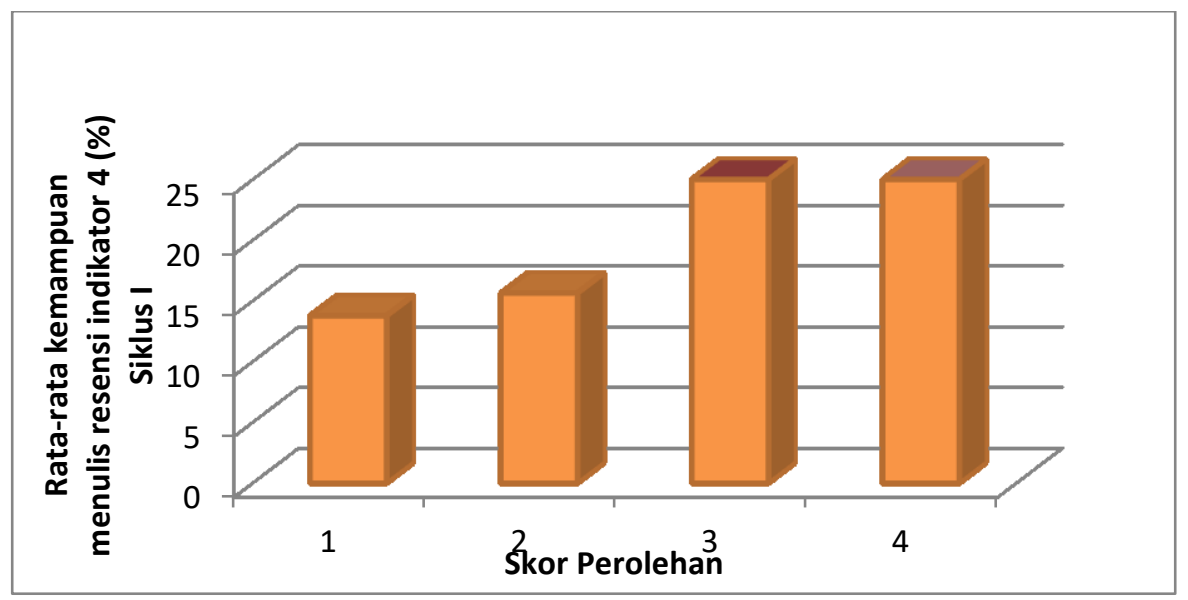

Gambar 7. Persentase Hasil Kemampuan Menulis Resensi Indikator 4

Bersadarkan Indikator 4 pada gambar 7 menunjukkan bahwa kemampuan mahasiswa menentukan bahasa pengarang dari buku yang diresensi, dari 32 mahasiswa hanya 8 orang yang dapat menentukan dengan sangat tepat bahasa pengarang atau hanya $25 \%$, menjawab dengan tepat 8 orang mahasiswa atau $25 \%$. Mahasiswa yang menjawab kurang tepat 5 orang atau 15,62\%. Sedangkan yang menjawab tidak tepat ada 12 orang atau $37,5 \%$.

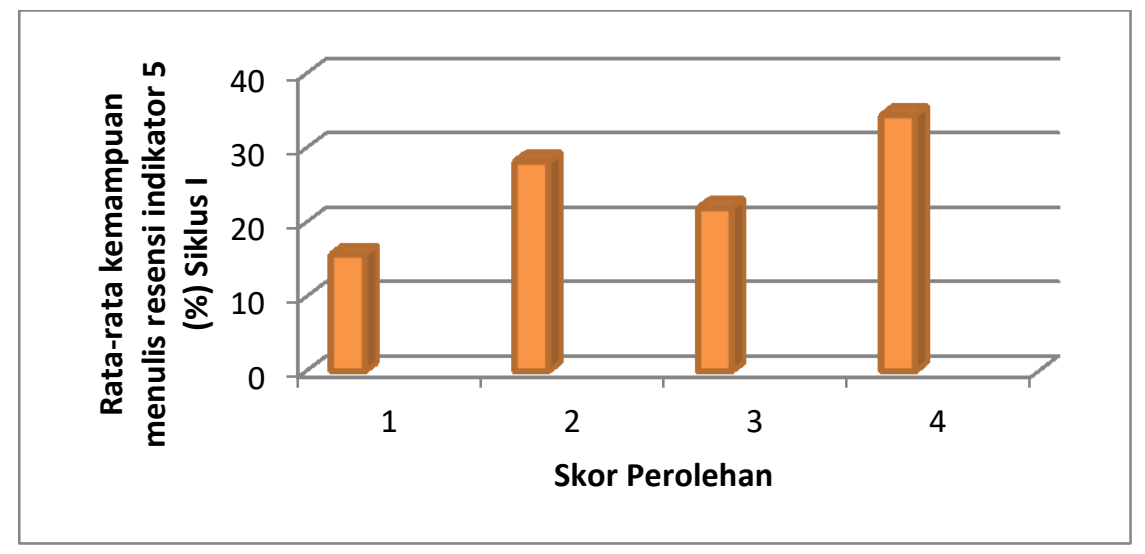

Gambar 8. Persentase Hasil Kemampuan Menulis Resensi Indikator 5

Berdasarkan Indikator 5 pada gambar 8 menunjukkan bahwa kemampuan mahasiswa menentukan keunggulan buku yang diresensi dari 32 mahasiswa terdapat 11 orang yang mampu menguraikan keunggulan buku dengan sangat tepat atau 34,37\%. 7 orang mahasiswa menguraikan dengan tepat atau $21,87 \%$. 9 orang mahasiswa yang menentukan kurang tepat atau 28,12\%. Sedangkan 5 orang mahasiswa atau 15,62 \% yang menjawab tidak tepat. 


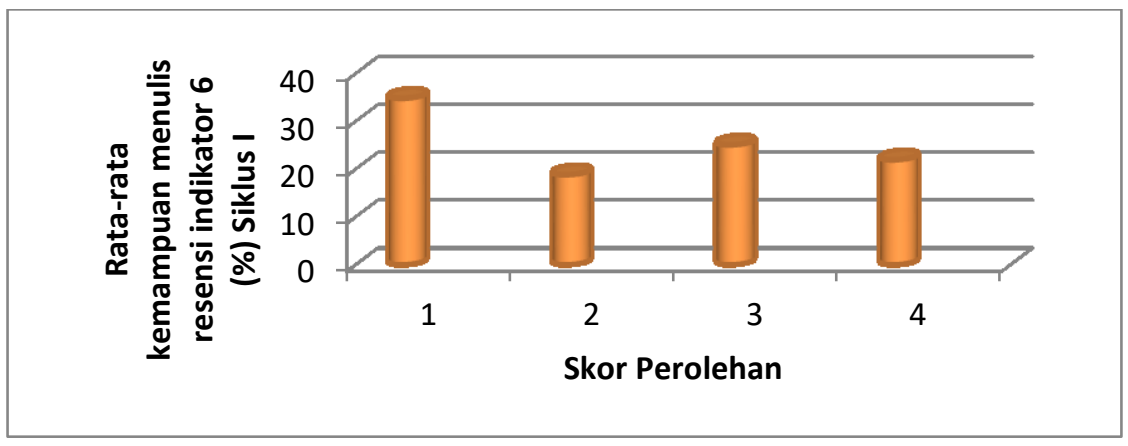

\section{Gambar 9. Persentase Hasil Evaluasi Indikator 6}

Berdasarkan Indikator ke 6 pada gambar 9, tampak kemampuan mahasiswa menentukan kelemahan buku yang diresensi dari 32 orang mahasiswa terdapat 7 orang yang mampu menguraikan kelemahan buku dengan sangat tepat atau 21,87\%, 8 orang mahasiswa menguraikan dengan tepat atau $25 \% .6$ orang mahasiswa yang menentukan kurang tepat atau $18,75 \%$. Serta ada 11 orang mahasiswa atau $34,75 \%$ yang menjawab tidak tepat.

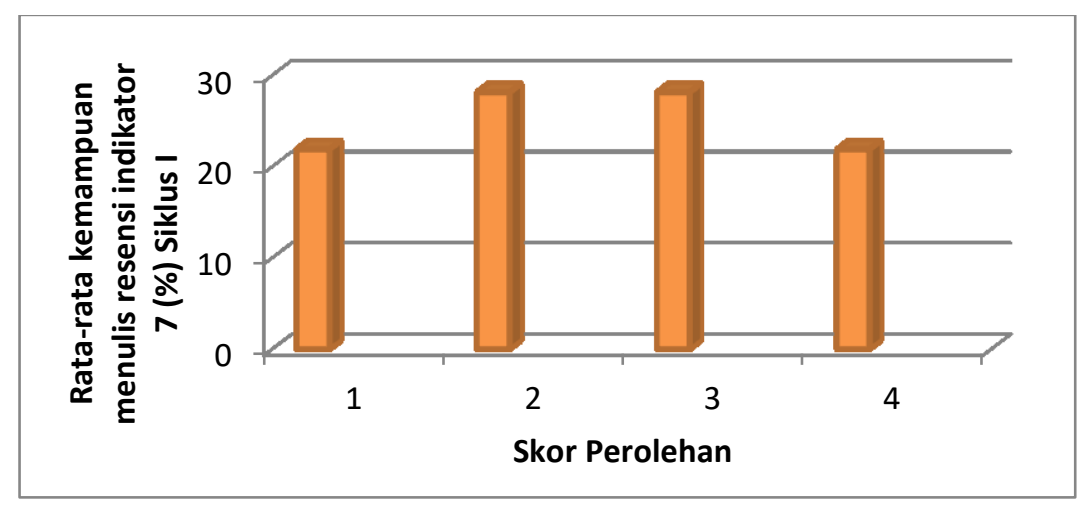

Gambar 10. Persentase Kemampuan Menulis Resensi Indikator 7

Berdasarkan indikator 7 pada gambar 10, menujukkan kemampuan mahasiswa menentukan kesimpulan buku yang diresensi dari 32 orang mahasiswa terdapat 7 orang mampu menguraikan kesimpulan buku dengan sangat tepat atau 21,87\%, 9 orang menguraikan dengan tepat atau 28,12 \%. Demikian juga, ada 9 orang yang menentukan kurang tepat atau sama dengan $28,12 \%$. Serta ada 7 orang atau $21,87 \%$ yang menjawab tidak tepat.

Berdasarkan Data di atas, menunjukkan adanya peningkatan kemampuan menulis resensi buku pendidikan anak usia dini dibandingkan dengan hasil sebelum diberikan tindakan dengan menggunakan pendekatan saintifik. Peningkatan keberhasilan secara klasikal dari $34,37 \%$ pada kemampuan awal menjadi $40,62 \%$ pada siklus I, sehingga terjadi peningkatan sekitar 6,25\%. Walaupun pada siklus I terdapat peningkatan hasil pembelajaran mahasiswa, namun jika dilihat secara perorangan belum mencapai kriteria ketuntasan minimal yang telah ditentukan oleh sekolah, sehingga perlu dilanjutkan ke siklus II.

\section{Refleksi dan Analisis Siklus I}

Bertolak dari hasil pengamatan dan evaluasi proses belajar mengajar siklus I yang telah dikemukakan di atas, diadakan diskusi dengan dosen mitra untuk memperoleh gambaran terhadap penyebab belum meningkatnya kemampuan mahasiswa dalam menulis buku yang diresensi, hal-hal yang belum dilakukan oleh dosen dalam proses belajar mengajar dan aktivitas mahasiswa yang belum memperlihatkan kemajuan dalam proses pembelajaran. 
Berdasarkan hasil pengamatan dosen mitra terhadap proses belajar yang dilakukan di dalam kelas menggambarkan bahwa sebagian besar kegiatan di dalam kelas masih kurang terlaksana dengan baik, seperti pada saat dosen menyampaikan, bahwa mahasiswa akan belajar dengan menggunakan pendekatan saintifik, meski ragu-ragu mahasiswa tampak senang dan tertarik. Sebaiknya di dalam proses pembelajaran baik eksak maupun non-eksakta digunakan pendekatan saintifik atau pendekatan ilmiah, agar mempermudah mahasiswa dalam memahami materi. Hal ini sependapat dengan Helmawati et al., (2015) bahwa pendekatan saintifik dipandang cocok untuk meningkatkan kemampuan menulis dan pemahaman materi mahasiswa, karena pendekatan saintifik memiliki langkahlangkah pembelajaran yang ilmiah dan jelas. Ketika dosen meminta mahasiswa untuk berkelompok, sebagian mahasiswa masih bertanya-tanya apa dan bagiamana melakukan langkah-langkah pembelajaran tersebut. Hal ini terjadi karena dosen dalam menjelaskan prosedur pembelajaran kurang dimengerti mahasiswa. Oleh karena itu, pada siklus berikutnya, dosen perlu menjelaskan prosedur pembelajaran yang lebih jelas dan bertanya kepada mahasiswa apa ada yang belum dimengerti.

Pada saat berdiskusi dalam kelompok sebaiknya dosen terus memantau kegiatan yang mereka lakukan, agar semua anggota kelompok bekerja dan memahami apa yang mereka lakukan, dengan demikian, perhatian mahasiswa akan terfokus dan seluruh anggota kelompok menjadi aktif. Ketika dosen memberikan pertanyaan berupa kuis, mahasiswa cukup antusias dalam menjawab, hal tersebut menyebabkan hanya sebagian mahasiswa yang mendapat bagian pertanyaan. Hal ini menjadi catatan untuk siklus berikutnya agar dosen lebih baik menyiapkan pertanyaan kuis yang lebih banyak sesuai jumlah mahasiswa agar tanya jawab kelas lebih seru.

Dalam menguraikan identitas buku, ada beberapa mahasiswa yang kurang cermat dalam melihat jumlah halaman buku. Hal ini diakibatkan mereka menganggap jumlah halaman tidak termasuk halaman judul, daftar isi, dan kata pengantar. Menentukan bahasa pengarang, mahasiswa kurang mampu menilai dan memahami buku yang mereka baca, masih ada yang menguraikan tentang bahasa buku, bukan dari segi pemahaman mereka. Begitu pula dalam menguraikan keunggulan dan kelemahan buku meski ada peningkatan tetapi peningkatannya tidak signifikan. Olehnya perlu ditindaklanjuti pada siklus II.

\section{Hasil Siklus II Evaluasi Kemampuan Menulis Mahasiswa Program Studi PG-PAUD}

Tahap penyajian data hasil belajar materi menulis resensi buku pendidikan anak usi dini dengan pendekatan saintifik pada siklus II telah dilakukan pengumpulan data sesuai prosedur, langkah selanjutnya adalah penyajian data hasil penelitian sesuai dengan tes yang dilakukan.

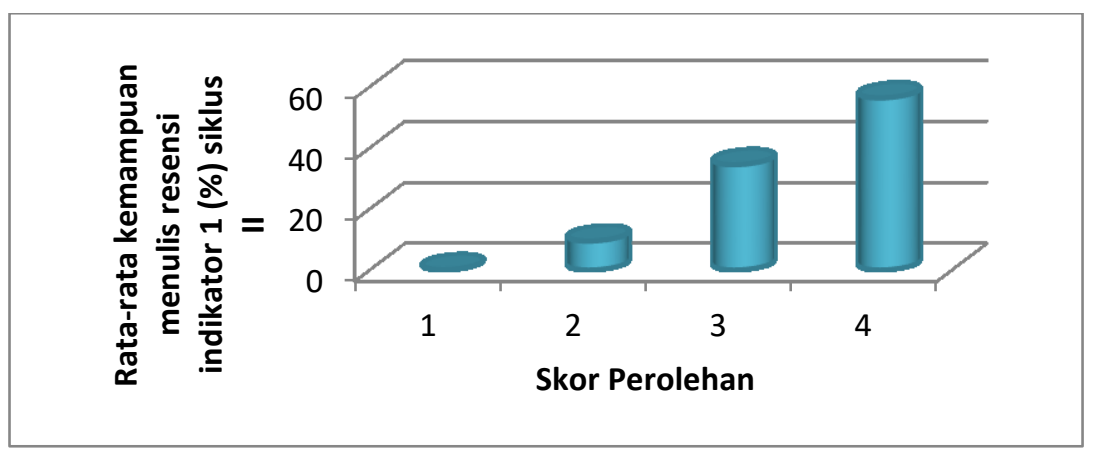

\section{Gambar 11. Persentase Hasil Penilaian Indikator 1 siklus II}

Berdasarkan gambar 11 di atas menunjukkan hasil kemampuan menulis resensi buku pendidikan anak usia dini pada siklus II. dari 32 orang mahasiswa untuk indikator (1) Menentukan judul resensi buku pendidikan anak usia dini ada 18 mahasiswa yang dapat 
menentukan judul sangat tepat atau 56,25 \%. Mahasiswa yang menjawab tepat 11 orang atau $34,4 \%$. Ada 3 orang mahasiswa yang menjawab kurang tepat atau 9,38\%, dan tidak ada mahasiswa yang menjawab tidak tepat.

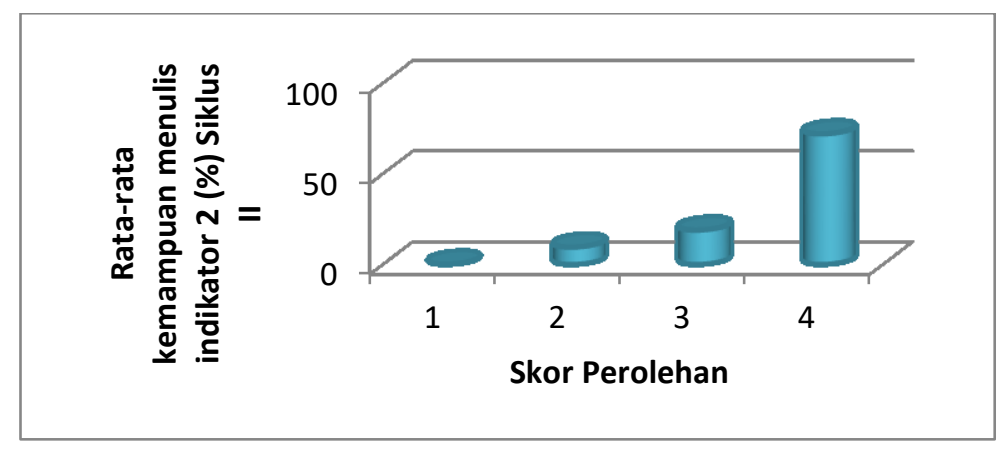

\section{Gambar 12. Persentase Hasil Penilaian Indikator 2 siklus II}

Berdasarkan gambar 12 di atas pada indikator 2 menunjukkan bahwa kemampuan mahasiswa menentukan identitas buku yang diresensi. Dari 32 orang mahasiswa yang sangat tepat dalam menuliskan identitas buku yang diresensi ada 23 orang mahasiswa atau $71,9 \%$. Mahasiswa yang tepat menentukan identitas buku berjumlah 6 orang mahasiswa atau $18,8 \%$. Sementara yang kurang tepat menentukan identitas buku yang diresensi ada 3 orang mahasiswa atau 9,38 \%, serta tidak ada mahasiswa yang menjawab tidak tepat.

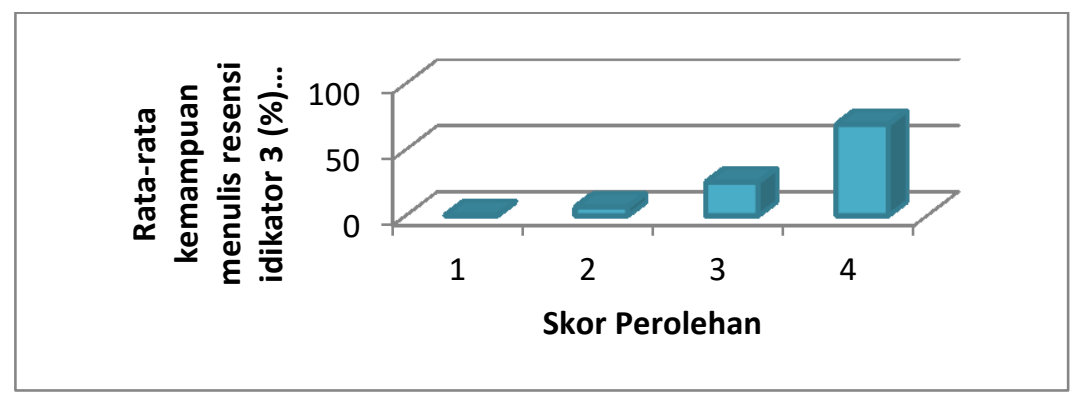

Gambar 13. Persentase Penilaian Indikator 3 siklus II

Berdasarkan gambar 13 di atas pada indikator 3, menunjukkan bahwa kemampuan mahasiswa menentukan isi atau materi penting resensi buku dari 32 orang mahasiswa 22 orang yang mampu menjawab dengan tepat, atau $68,75 \%$, ada 8 orang mahasiswa yang menjawab tepat atau $25 \%$, sementara mahasiswa yang kurang tepat menguraikan isi materi berjumlah 2 orang atau 6,25\%. Sedangkan mahasiswa yang menjawab tidak tepat tidak ada.

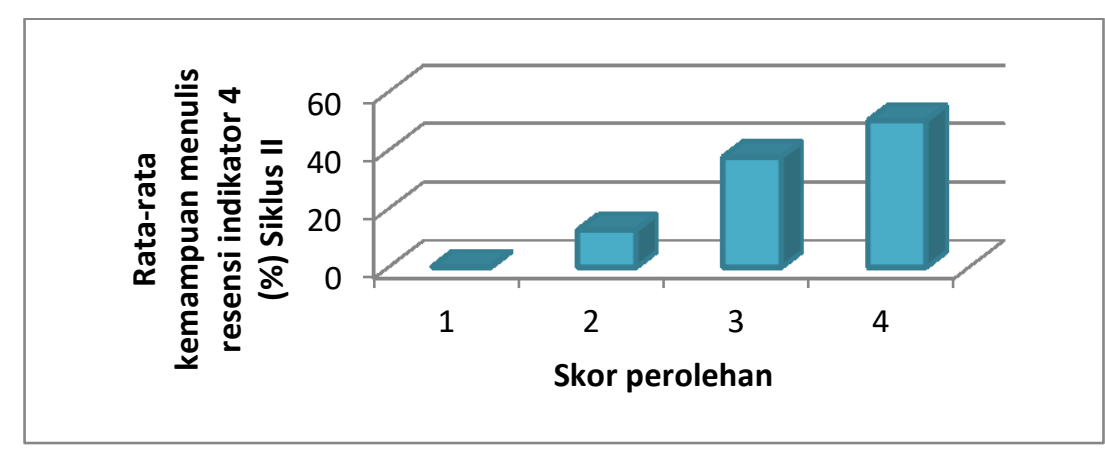

Gambar 14. Persentase Penilaian Indikator 4 siklus II 
Berdasarkan gambar 14 di atas pada indikator 4, menunjukkan bahwa kemampuan mahasiswa menentukan bahasa pengarang dari buku yang diresensi, dari 32 mahasiswa ada 16 orang yang dapat menentukan dengan sangat tepat bahasa pengarang atau $50 \%$, begitu pula yang menjawab dengan tepat 12 orang mahasiswa atau 37,5\%. Mahasiswa yang menjawab kurang tepat 4 orang mahasiswa atau 12,5\%. Sedangkan yang menjawab tidak tepat tidak ada.

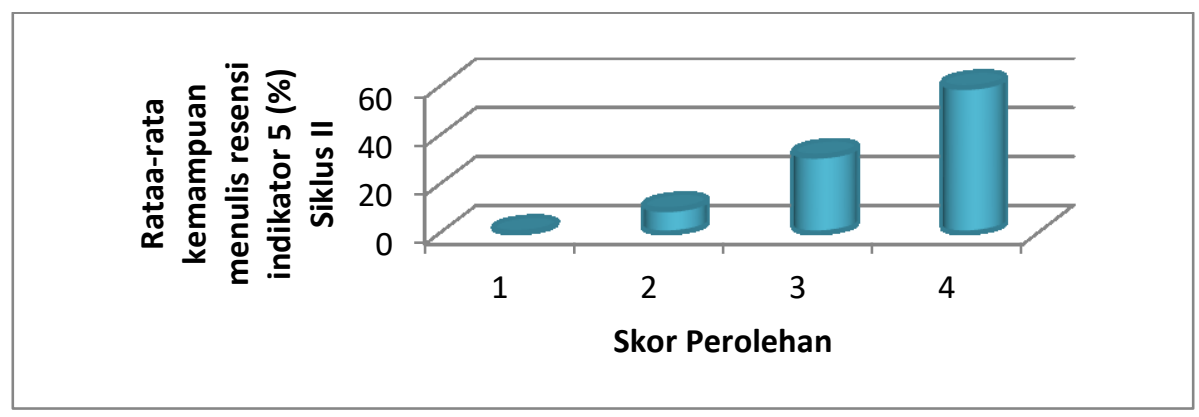

Gambar 15. Persentase Penilaian Indikator 5 Siklus II

Berdasarkan gambar 15 di atas pada indikator 5 menunjukkan bahwa kemampuan mahasiswa menentukan keunggulan buku yang diresensi dari 32 mahasiswa 19 orang mahasiswa mampu menguraikan keunggulan buku dengan sangat tepat atau 59,37 \%, 10 orang mahasiswa menguraikan dengan tepat atau 31,25\%. Ada 3 orang mahasiswa yang menentukan kurang tepat atau 9,37 \%. Sedangkan yang menjawab tidak tepat tidak ada.

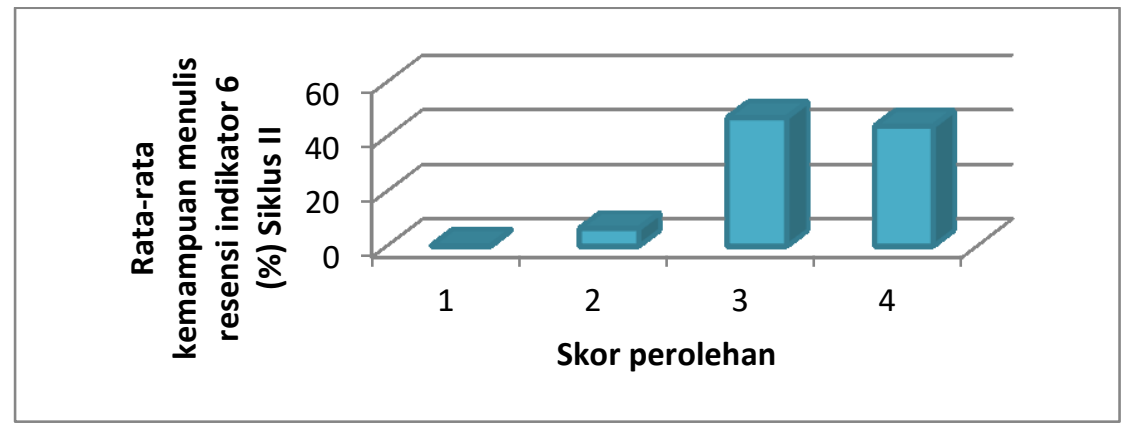

Gambar 16. Persentase Penilaian Indikator 6 Siklus II

Berdasarkan gambar 16 pada indikator 6, menunjukkan bahwa kemampuan mahasiswa menentukan kelemahan buku yang diresensi dari 32 orang mahasiswa 14 orang mahasiswa mampu menguraikan kelemahan buku dengan sangat tepat atau 43,75\%, begitu pula mahasiswa dalam menguraikan kelemahan buku dengan tepat berjumlah 15 orang atau $46,88 \%$. Sedangkan yang menjawab kurang tepat dan tidak tepat masing-masing 3 orang mahasiswa atau $6,25 \%$. Sedangkan yang menjawab tidak tepat tidak ada.

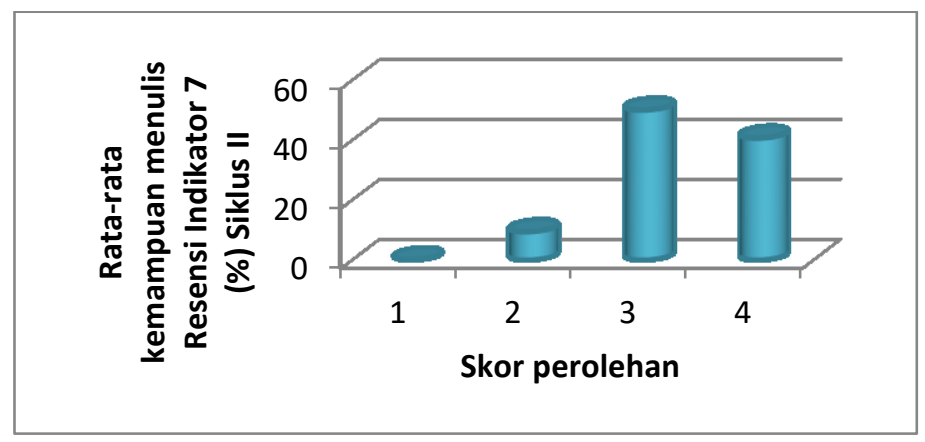

Gambar 17. Persentase Penilaian Indikator 7 Siklus II 
Berdasarkan gambar 17 di atas pada indikator 7, menunjukkan bahwa kemampuan mahasiswa menentukan kesimpulan buku yang diresensi dari 32 orang mahasiswa 13 orang mahasiswa mampu menguraikan kesimpulan buku dengan sangat tepat atau 40,63 \%, ada 16 orang mahasiswa menguraikan dengan tepat atau $50 \%$. Demikian juga, ada 3 orang mahasiswa yang menentukan kurang tepat atau sama dengan 9,37\%. Serta tidak ada mahasiswa yang menjawab tidak tepat. Peningkatan keberhasilan secara klasikal dari 66,41 pada siklus I, menjadi 86,77 \% pada siklus II jadi terjadi peningkatan sekitar 20,36 \%.

\section{Refleksi dan Analisis Siklus II}

Berdasarkan hasil analisis Sebagian besar dari langkah-langkah pembelajaran pada siklus II ini dapat terlaksana dengan baik. Mahasiswa sudah mampu bekerja sesuai dengan petunjuk yang ada. Begitu pula dalam menjawab pertanyaan kuis yang diberikan dosen, hampir seluruh mahasiswa dapat menjawab pertanyaan dengan benar. Dalam memaparkan hasil pekerjaan pun mahasiswa tidak ragu-ragu dalam menyampaikan. Berbeda dengan siklus I, yang tampak tidak percaya diri dalam memberikan argumen terhadap apa yang telah dikerjakan.

Pendekatan saintifik merupakan pendekatan yang tepat dalam meningkatan kemampuan dan pemahaman pada peserta didik. Hal ini sependapat dengan Bermawi \& Fauziah (2017) bahwa pendekatan saintifik memberikan pemahaman kepada peserta didik dalam hal mengenal dan memahami berbagai materi yang disampaikan. Berdasarkan hasil penelitian yang dilakukan bahwa mahasiswa mampu bekerja sesuai dengan petunjuk yang ada hal ini dibuktikan bahwa 32 orang mahasiswa mengalami peningkatan secara klasikal dari siklus I yakni $66,41 \%$, pada siklus II menjadi $86,77 \%$ sehingga terjadi peningkatan $20,36 \%$.

\section{SIMPULAN}

Jika dicermati simpulan penelitian ini mempunyai implikasi pada mahasiswa PGPAUD dan pendidik agar lebih memperkuat pembelajaran melalui penggunaan pendekatan saintifik. Pendekatan saintifik lebih membuka wawasan mahasiswa dalam meningkatkan kemampuan menulis resensi buku pendidikan anak usia dini, karena sesungguhnya pendekatan saintifik adalah pendekatan yang efektif dalam memberikan pemahaman kepada mahasiswa.

\section{UCAPAN TERIMAKASIH}

Peneliti ucapkan terma kasih pada pihak yang terlibat khususnya Universitas Negeri Gorontalo yang telah memberikan izin untuk melaksanakan penelitian ini.

\section{DAFTAR PUSTAKA}

Agustin, M. (2017). Peningkatan Kemampuan Menulis Puisi Bebas. Jurnal DIKSATRASIA, 1(April), 2010-2012.

Alwiyah, D., \& Imaniyati, N. (2018). Keterampilan Mengajar Guru Dan Kesiapan Belajar Siswa Sebagai Determinan Terhadap Hasil Belajar Siswa. Jurnal MANAJERIAL, 17(1), 95. https://doi.org/10.17509/manajerial.v17i1.9767

Ansoriyah, S., \& Rahmat, A. (2018). Peningkatan Kemampuan Menulis Populer Mahasiswa Melalui Pendekatan Whole Language dengan Pembuatan Media Story Board. AKSIS Jurnal Pendidikan Bahasa Dan Sastra Indonesia, 2(1), 29-46. https:// doi.org/10.21009/AKSIS.020103

Bermawi, Y., \& Fauziah, T. (2017). Penerapan Pendekatan Saintifik Dalam Pembelajaran Di Sekolah Dasar Aceh Besar. Jurnal Pesona Dasar, 2(4), 63-71.

Gereda, A. (2014). Kemampuan Menulis Deskripsi Mahasiswa Program Studi Pendidikan Bahasa dan Sastra Indonesia Universitas Musamus. MAGISTRA, 2(1), 125-137. https://doi.org/doi.org/10.35724/magistra.v2i1.325 
Helmawati, Raja, P., \& Samhati, S. (2015). Peningkatan Kemampuan Menulis Melalui Pendekatan Saintifik Pada Peserta Didik SMA. J-Simbol (Bahasa, Sastra, Dan Pembelajarannya).

Hulukati, W., \& Rahmi, M. (2020). Jurnal Obsesi: Jurnal Pendidikan Anak Usia Dini Instrumen Evaluasi Karakter Mahasiswa Program Pendidikan Guru Pendidikan Anak Usia Dini Abstrak. 4(2), 851-861. https://doi.org/10.31004/obsesi.v4i2.468

Jayaningrum, M., Djumahana, N., \& Mulyasari, E. (2019). Penerapan metode drill untuk meningkatkan kemampuan menulis ejaan bahasa indonesia. Jurnal Pendidikan Guru Sekolah Dasar, 4(II), 14-25. https://doi.org/10.17509/jpgsd.v4i2.20558

Kemmis, S., \& Mc Taggart, R. (1998). The Action Research Planner (Third Edit). Deakin University.

Komaidi, D. (2007). Aku Bisa Menulis (Panduan Praktis Menulis Kreatif Lengkap). Sabda Media.

Laia, A. (2016). Penerapan Pendekatan Saintifik Untuk Meningkatkan Kemampuan Menulis Puisi Siswa Kelas VIII SMP Negeri 3 Onolalu Tahun Ajaran. Jurnal Education and Development STKIP Tapanuli Selatan, 3(3), 99-106. https://doi.org/10.37081/ed.v3i3.497

Maiza, Z., \& Nurhafizah, N. (2019). Pengembangan Keprofesian Berkelanjutan dalam Meningkatkan Profesionalisme Guru Pendidikan Anak Usia Dini. Jurnal Obsesi: Jurnal Pendidikan Anak Usia Dini, 3(2), 356. https:/ / doi.org/10.31004/obsesi.v3i2.196

Miles, M., \& Huberman, M. (2007). Analisis Data Kualitatif. UI Press.

Muhson, A. (2004). Meningkatkan Profesionalisme Guru: Sebuah Harapan. Jurnal Ekonomi $\mathcal{E}$ Pendidikan, 2(1). https://doi.org/10.21831/jep.v1i2.665

Musaffak. (2013). Peningkatan Kemampuan Menulis Makalah Mahasiswa Pengambilan Matakuliah Bahasa Indonesia Keilmuan Jurusan Pendidikan Bahasa Inggris FKIP UMM Semester II 2012 dengan Strategi Peta Pikiran. Jurnal Pendidikan Humaniora, 1(4), 354-366.

Nugraha, J., Fuad, N., \& Jakarta, U. N. (2019). Peningkatan keterampilan menulis deskripsi melalui pendekatan saintifik dengan metode problem based learning di kelas iv sekolah dasar. Prosiding Seminar Nasional Pendidikan KALUNI, 2, 118-124. https://doi.org/10.30998/prokaluni.v2i0.37

Nugraha, V., Permana, I., \& Permana, A. (2018). Pembelajaran Menulis Resensi Novel Pertemuan Dua Hati dan Laskar Pelangi Menggunakan Teknik. Jurnal Ilmiah P2M STKIP Siliwangi P2M STKIP Siliwangi, 5(2), 1-6. https://doi.org/10.22460/p2m.v5i2p55-61.966

Pebriana, P. H. (2017). Analisis Kemampuan Berbahasa dan Penanaman Moral Pada Anak Usia Dini Melalui Metode Mendongeng. Jurnal Obsesi : Journal of Early Childhood Education, 1(2), 139-147. https://doi.org/10.31004/obsesi.v1i2.34

Persadha, D. A. K. (2016). Studi Kompetensi Kemampuan Menulis. MUADDIB, 6(1), 1-20. https://doi.org/10.24269/muaddib.v6n1.2016.1-20

Setiawan, D. (2017). Pendekatan Saintifik Dan Penilaian Autentik Untuk Meningkatkan Mutu Pembelajaran Pendidikan Agama Islam. AL-ASASIYYA: Journal Of Basic Education, 1(2), 34-46. https:// doi.org/10.24269/ajbe.v1i2.683

Sulistia-dewi, E. (2018). Meningkatkan Kemampuan Menulis Mahasiswa dengan Pengintegrasian Powers dalam Asessmen Portofolio Elektronik. Pendidikan Indonesia, 2(2). https://doi.org/10.23887/jpi-undiksha.v2i2.2169

Sum, T. A., \& Taran, E. G. M. (2020). Kompetensi Pedagogik Guru PAUD dalam Perencanaan dan Pelaksanaan Pembelajaran. Jurnal Obsesi : Jurnal Pendidikan Anak Usia Dini, 4(2), 543. https://doi.org/10.31004/obsesi.v4i2.287

Suyanto. (1997). Pedoman Pelaksanaan Penelitian Tindakan Kelas (PTK). BP3SD Dirijen Dikti Depdikbud.

Wakhidah, N. (2018). Pembelajaran dengan pendekatan saintifik terhadap kemampuan berpikir kritis mahasiswa calon guru madrasah ibtidaiyah. Premiere Educandum: Jurnal Pendidikan Dasar Dan Pembelajaran, 8(2), 150. https://doi.org/10.25273/pe.v8i2.2950

Zubaidi, M. (2020). Jurnal Obsesi: Jurnal Pendidikan Anak Usia Dini Profesionalisme Guru dan Efektivitas Pembelajaran pada Pendidikan Anak Usia Dini Abstrak. 4(2), 1060-1067. https://doi.org/10.31004/obsesi.v4i2.505 